\title{
Geological Map of the People's Republic of China (1:2 500 000)
}

\section{Introduction}

The Geological Map of the People's Republic of China with Chinese and English versions was published by the SinoMaps Press in 2004 at the scale of 1:2 500000 , including 8 sheets. The chief compiler is Huang Chongke, and the associate chief compilers are Ye Tianzhu, Chen Keqiang, Wu Kuanlian, Ji Xiaoyan, Gao Zhenjia, Qian Dadu, Tian Yuying, He Yongxiang, Zhang Qinghe, Cao Banggong, Li Long, Shao Heming, Wang Yongqin, Yang Minggui, Zhang Zhongwei, Yao Dongsheng and Zheng Jiankang. More than 100 geologists, cartographers and members of computer mapping took part in the compilation of the map.

In the 1950s, 1:200 000-scale systematic geological mapping launched in China, and up to 2000, it covered an area of $72 \%$ of continental China. At the same time, $18.40 \%$ of continental geology of China were mapped in 1:50 000-scale, and by 1995, 1:10 000000 -scale geological mapping of the whole country was also finished. Since 1970s, 1:30000 000-scale and 1:20 000 000scale geological maps of China, 1:10 000 000-scale multi-sheet geological map of China and 1:500 000-scale geological maps of most of the provinces and autonomous regions have been compiled successively. The 1:40 000 000-scale and 1:50 000 000-scale geological maps of China, and the 1:50 000 000-scale Asian Geological Map and the Geological Atlas of China have been published. For the purpose of a systematic generalization of the results of regional geological survey, a series of Geological Memoirs, the Regional Geology and related geological maps of 30 provinces, municipalities and autonomous regions, sponsored by the former Ministry of Geology and Mineral Resources of China, were compiled and published from 1981 to 1989 . The total volume of the Regional Geology includes 90 sheets of 1:500 000 and 1:20 000 000- scale geological maps (geological map, magmatic rock map, geological structure map as well as metamorphic rock map, volcanic rock facies structure map, bedrock geological map and Quaternary geology map of some of the provinces). All these attainments promoted the study of regional geology, mirrored the present knowledge of fundamental geological science, and vividly revealed the spectacular regional geological characteristics of China.

The Program "1:2 500 000-scale Digital Geological Map, Spatial Database of PRC" (English Edition) was assigned by the China Geological Survey (CGS) on 15 April, 2003. The Program is an item of the Project 'The Compilation of National Comprehensive Fundamental Geological Maps' which is to edit and publish the 1:2 500,000-scale Digital Geological Map (English Edition) based on its Chinese Edition. The 1:2 500 000-scale Geological Map of the People's Republic of China was compiled with new results of the 115 sheets of 1:50 000- and 1:250 000-scale geological maps done in 1999 to October, 2002 and many research results. In particular, the new data from the 39 sheets of 1:250 000-scale geological map of the Qinghai-Tibet plateau and its adjacent area have greatly enriched the knowledge of the geological-structural outlook of the west China.

The 1:2 500 000-scale Geological Map of the People's Republic of China covers the area from east longitude $60^{\circ}$ to $152^{\circ}$ and north latitude $14^{\circ}$ to $56^{\circ}$. The map is compiled with normal-conformal conic projection, central longitude $110^{\circ}$ and standard latitude $25^{\circ}$ and $47^{\circ}$.

\section{Main characteristics of the Map}

1. The stratigraphic division in the Map is based on the new scheme of the Chronostratigraphy Table, adopted by The Third National Conference of Stratigraphy of China and approved by the Ministry of Land and Resources with reference of the Table of International Geochronology. The previous Paleogene (Old Tertiary) is changed to Eogene (E), and New Tertiary is named as Neogene $(\mathrm{N})$; Permian is tripartite, and the previous part of the upper Carboniferous is re-classified to lower Permian $\left(\mathrm{P}_{1}\right)$; Silurian is divided as lower $\left(\mathrm{S}_{1}\right)$, middle $\left(\mathrm{S}_{2}\right)$, upper $\left(\mathrm{S}_{3}\right)$ and top series $\left(\mathrm{S}_{4}\right)$; the time of the Cambrian and Sinian boundary is changed to $543 \mathrm{Ma}$; a new Nanhua System (Nh) and two series $\left(\mathrm{Nh}_{1}\right)$ and $\left.\mathrm{Nh}_{2}\right)$, composed of the previous lower Sinian, are established, and its time ranges 680-800 Ma. The previous upper series of Sinian is changed to Sinian System (Z); Hutuo System (Ht) is newly established in Proterozoic Erathem, and its time span is $1800-2300$ Ma; Archaean Eonothem is quadrupartite, and the metamorphic rock system older than $3600 \mathrm{Ma}$ is newly established as a chronologic unit-Eo-Archaean $\left(\mathrm{Ar}_{0}\right)$; the previous Palaeo-Archaean, Meso-Archaean and Neo-Archaean are kept unchanged both in time span and in boundary.

Sedimentary stratigraphy (including volcano-sedimentary stratigraphy) is marked on the map as chronostratigraphic unit with accuracy to series or (minor) trans-series. Some less-studied stratigraphic units or those too narrow to be shown on the map are expressed in system, and a few individual units are integrated to "sub-erathem". As a result, 90 erathems, 180 systems and 590 series of straitgraphic units and 1590 transitional trans-series and trans-system geochronological units are shown on the map. Three types of lithofacies-marine facies, continental facies and paralic facies - are marked by different letter symbols for Triassic chronostratigraphic units. Quaternary system is shown with chronostratigraphic units and genetic types. Those genetic types of Quaternary stratigraphy closely related to human living and production, when necessary, are exaggerated on the map. For the established rock formations, only a few representative ones are shown on the map. The chronostratigraphic units of Pleistocene are expressed as $\mathrm{Qp}^{1}, \mathrm{Qp}^{2}, \mathrm{Qp}^{3}$, and Holocene as $\mathrm{Qh}$.

2. Magmatic activities occurred frequently in the geological history of China. From early to late, magmatic activities can be divided into 10 periods. They are pre-Lüliangian, Lüliangian, Sibaoan, Jinningian, Sinian, Caledonian, Variscan, Indosinian, Yanshanian and Himalayan, covering a time span of more than $2500 \mathrm{Ma}$. Each period can be subdivided into early-, mid- and latesubperiods, or sometimes early subperiod and late subperiod. The forms of magmatic activities can be intrusive, effusive, eruptive and eruptive-sedimentary. Magmatic rock types in China are diverse, including ultramafic, mafic, intermediate, intermediate-acidic to acidic, and alkalic. Each type consists of many kinds of magmatic rocks. The classification of magmatic rocks and their terminology are based on the QAPF Classification and Terminology Scheme, suggested by the IUGS in 1989 .

Magmatic rocks are expressed as lithological plus chronological units. Altogether 290 rock associations of five-type magmatic rocks are shown on the map, in which 50 for ultramafic rocks, 50 for mafic rocks, 30 for intermediate rocks, 30 for alkalic magmatic 
rocks and 130 for acidic-intermediate to acidic rocks. In addition, five types of metamorphic plutonic intrusive rocks and one type of volcanic rock, of sub-volcanic rock and of migmatite, are classified respectively.

The continental volcanic rocks of Mesozoic in east China and the volcanic rocks in some stratigraphic units of late Palaeozoic in west China are expressed on the map as duplicated display of stratigraphic patterns superimposed with lithological patterns of volcanic rocks.

3. On the map, important localities of specific rock types, such as miarolitic granite, rapakivi granite, glaucophane schist, eclogite and ophiolite are shown. In recent decade, coesites and diamonds in eclogite were discoveried in Dabieshan Mt.-Jiangsu-Shandong (Sulu, in short) and the existence of ultra-high pressure (UHP) metamorphic belt was determinated.

4. Early pre-Cambrian metamorphic rock systems are classified as supracrustal rocks and metamorphic plutonic rocks. The former are shown as chronostratigraphic units, while the latter are shown by special symbols and patterns to distinguish them from the traditional intrusive rocks.

5. China can be divided into 4 major tectonic system domains (Paleo-Asia, Tethys, Cathaysia-Marginal West Pacific, and HelanKangdian), 7 ancient plates (Yangtze, Cathaysia or Huaxia, Tarim, North China, Philippine Sea, Gangdisê-Indian) and 4 micro-plates or group of massifs (Junggar-Ili, Jiamusi-Songnen, Qilian-Qaidam and Changdu-Gangdisê).

6. Faults are shown in two groups on the map: important and conventional faults. The former represent the main regional faults that are structurally significant with great dimension, generally stretching across provinces or regions. Some important hidden faults with compelling geophysical evidence or remote sensing interpretation are also shown in covered areas. 89 most important regional faults are displayed, among them 45 faults are active where earthquakes (magnitude more than 6) have taken place. They are distributed in various tectonic system domains, of which 6 are plate junctures, 6 important micro-plate joint belts, and 10 crustal mosaic zones. In most of them, ophiolite zones are visible, structural mélange zones are developed, and large-scale ductile shear zones are followed. In 16 of these faults, blueschist belts have been discovered. The coesite-bearing eclogite of ultra high pressure (UHP) metamorphic belt is found only in the Central Orogenic System.

\section{Digital mapping and database}

On the basis of the Spatial Data Base of the 1:500 000-scale Digital Geological Map of PRC jointly sponsored by the former National Committee of Planning and the Ministry of Geology and Mineral Resources, the 1:2 500 000-scale Digital Geological Map of $P R C$ was compiled and its spatial database was established at same time in 2003.

The data of the 1:2 500 000-scale Digital Geological Map Spatial Database of PRC is 600 MB. In the database, 5421 areal elements of chronostratigraphic units, 2286 areal elements of magmatic intrusive units, 473 areal elements of Quaternary genetic units, 33 glaucophane schists (belts), 124 eclogites, 74 ophiolites(belts), 180 miarolitic granites, 756 faults of 1-2 order, 4 palaeo-anthropologic relics, 1452 samples of isotopic dating, 147 drill holes in Quaternary sediment were collected. In addition, 2 kinds of administrative regions, 4 kinds of administrative boundaries, 7 kinds of living areas, 4 kinds of highways, one kind of railway, 3 kinds of rivers, 4 kinds of lakes, 3 kinds of marine elements and 4 kinds of geomorphology were stored in the geographic base map database. CAD technology was used in compilation of the maps on the MAPGIS 6.2 platform with high precision and good quality to meet the requirements of the Project. It is the first 1:2 500 000-scale digital geological map spatial database with most abundant and newest materials and is the first to use GIS technology, which reflects the new knowledge of geological-structural features of China and the new level of digitalized geological database technology of the country.

\section{To order the map:}

Ding Xiaozhong

Institute of Geology

Chinese Academy of Geological Sciences

26, Baiwanzhuang Dajie

Beijing 100037

CHINA

E-mail:Xiaozhongding@Sina.com

Telephone:+86-10-68999675

(The price of the English version of the map is US\$150.)

\section{Ding Xiaozhong and Chen Keqiang}

Institute of Geology,

Chinese Academy of Geological Sciences,

Beijing 100037,

CHINA

Huang Chongke and Ye Tianzhu

China Geological Survey,

Beijing 100011,

CHINA 
